\title{
STUDY THE DETERIORATION OF GRANITE STATUES, KEMAN FARES EXCAVATIONS, FAYOUM, EGYPT
}

\author{
Shehata, A, Abdelrahim \\ Conservation Department, Faculty of Archaeology, Cairo University, \\ fayoum Branch, Egypt
}

(Received November 14, 2005 Accepted November 26, 2005)

The Main Temple of The Keman Fares built in the beginning of Middle kingdom. Different Granite statues are excavated in this site.

The analytical study of the deterioration of the granite statues are made by using different analytical techniques such as thin section and scanning electron microscope.

This study examines the physicochemical environments of Keman Fares Temple. Also this paper is based on the research carried out to determine the environmental deterioration on the degradation of the Granite statues. The samples were studied by X- ray diffraction (XRD), Energy dispersive $\mathrm{X}$ - ray analysis and $\mathrm{X}$-ray fluorescence to find out the deterioration intensity on these statues.

\section{INTRODUCTION}

One of its names "sdyt" which located to the north of Fayoum, and was built by King "Menes"" which immediately "Keman Fares", Fig. 1. The city was flourished in Middle Kingdom especially during the reign of king "Amenmhat" because the native of the city considered him as a god [1]. To the north of the city located the excavation in the main temple which was built in the beginning of Middle Kingdom. The old resources mentioned that the floor of the temple was from pink granite and its entrance from gold leaves [2].

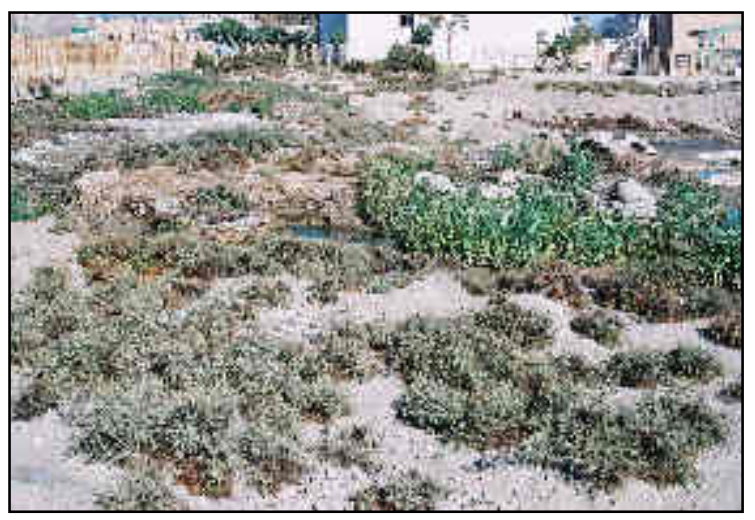

Fig. 1: General View of keman shows the raising of groundwater and urbanization effect on the granite satatues. 
Inside the temple it was found two statues for the king "Amenmhat 1" with the priestly costume which in Egyptian Museum N.395 [3]. The remain or ruins of monuments proves that the city was developed from Predynastic period to GreceRoman period. The temple of sdyt was built by the king "Amenmhat 1" who wasn't the founder because the temple was built during the old kingdom [4]. When king "Amenmhat1" added row of granite columns. Then the king "Amenmhat 1" a great hall was added in Ramssid period, some additions to the temple their in late period. But the temple was vanished, some remains exists in the place like Vessels and statue from black granite.

1- Statue of King Ramses to the Sobek temple in "Sdyt" City from the statue the remain of temple was very good and great.

2- Statues of princes and Scribes in the area of temples within "sdyt" city.

All the Granite statues are examined to study the deterioration of Granite using different analytical methods. All the environmental decays were described.

\section{ENVIRONMENTAL DECAY}

The expansion and contraction of Sun lead to breaking, flaking and disintegration of the granite statues. The temperature changes are not only sufficient to cause the disintegration of granite, the pollution, humidity or moisture and groundwater represent important factors for the disintegration of granite statues [5]. At El-Fayoum, the relative humidity in the morning varies from 28 to $58 \%$ averaging $39 \%$. At Fayoum there are several light showers each year. There is moderately heavy dew fall at night and the relative humidity at morning run from 64 to $87 \%$. In case of the exfoliation statues, the exfoliation connected with the lower part of statues near by the temple floor whereas the effect of the underground water appears. Many statues show several deterioration and rapid rates of disintegration. Figure 2 shows exfoliation and flakes of a thin film, spalling, scattered patchy, flaking and under tapping in granite statues.

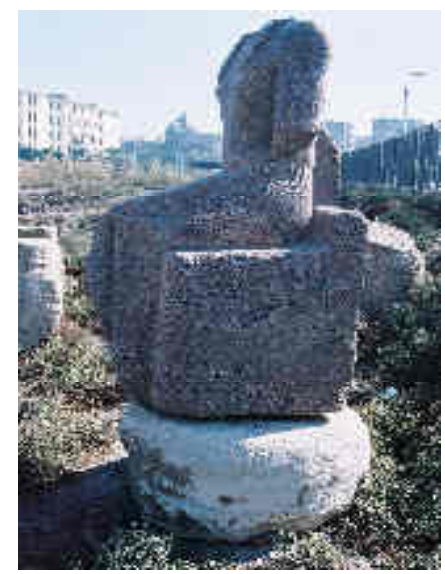

Fig. 2: Exfoliation of granite statues.

The diurnal temperatures can reach at $70^{\circ} \mathrm{C}$ and drop rapidly. These effects alone can be sufficient to cause the superficial granular disintegration [6]. Some statues 
show slight roughening where as individual grains of feldspars and quartz become lossened and show superficial granular disintegration [7, 8]. By extensive alternation the exposed surface of minerals granite commonly falls a part grain by grain during a long time. In the case of the intensive granular disintegration, many feldspars and quartz grains become lossened and shows roughen appearance. In this site, the most important Phenomena, is the granular disintegration by growth of salt crystals within the pores from the microcracks of the stone. Monuments in the regions of semi-humid moderate climate may be readily saturated with salts introduced from polluted air and ground water sources [9]. In the granular disintegration, many feldspar and quartz grains lossened and show roughen appearance in the fine grained granite statues, the hydration of salts take place within fractures and microcracks, produced sufficient stress causes intensive spalling.

The hydration of salts can be effective in promoting stone disintegration. The volume of expansion of over 300 percent can be obtained from absorption of water during hydration of salts within pores from the cracks of stones develops sufficient stress to cause an extensive spalling or flaking [7, 10]. The development and growth of salt crystals have an effect when water groundwater is down to the surface of granite statues through joints, fractures and micro cracks by capillary force [11]. This water carries mineral salts. As evaporation take place, minute salt crystals remain behind and tiny salt crystals are disseminated throughout the crystal and the salt efflorescence are developed at the expense of feldspar crystals. The disruptive of the salt crystallization between the feldspar, biotite, quartz grains is capable of disintegration, producing internal disintegration in the coarse grained granites. The evaporative surface of the granite is disaggregated quite rapidly [6]. The final result is the crumbling of the thin surface layer of coarse grained statues.

When water thraw within the cracks and fractures of such stones evaporates away small residual salt crystals form. This growth of those tiny crystals pries the salt wedging process and weakens their internal structure. In the site the groundwater is drawn to the surface of the statues through cracks and micro-fractures by capillary force. As evaporation takes place minute salt crystals grow in hidden fractures [12]. The granite statues shattered as angular fragments by the growth of salt crystals along minute cracks and fractures and microcracks allow the penetration of salt and acid solutions formed from pollutants present in the atmosphere.

The granite statues are seriously damaged. A proof of the salt aggressiveness is the disintegration of granite statues, columns and blocks in the area where they stood above ground migration of groundwater and wear soluble salts into granite statues. The process of water evaporation makes the salts crystallize on the stone surface, thus damaging it.

The main weathering forms in the Keman fares are granular disintegration, plates, scales, flakes, exfoliation, efflorescence and Microbiology colonization Figs. 2, 9. The soluble salts are also responsible for granular disintegration. The high intensity of granular disintegration is associated with a high concentration of salts. The most common salts occurring in efflorescence are Sulphates, chlorides, nitrates and magnesium chloride. Salts are extremely dangerous, because they are very soluble, hygroscopic and redissolved. They are very mobile and thus they penetrate and break up many crystalline structure. 
Granular disintegration (Fig. 3) is responsible to the loss of granite material. The statues show the loss of hardness and polish leading to minerals alteration. The textural anisotropy of the granite leads to the grow of cracks while progress its physical deterioration giving rise to planes of weakness. The degradation of granite materials decays tends to be by exfoliating (Figs. 2,3). Also weathering and kaolonization of granite statues observed in Fig. 4.

Also Biocolonization is present (Fig. 5) moreover, plant roots commonly grow in the fractures of granite stones and impacts the Amenhotep III statues (Figs. 1, 5). Destruction of grainte statues are shower in Fig. 6.

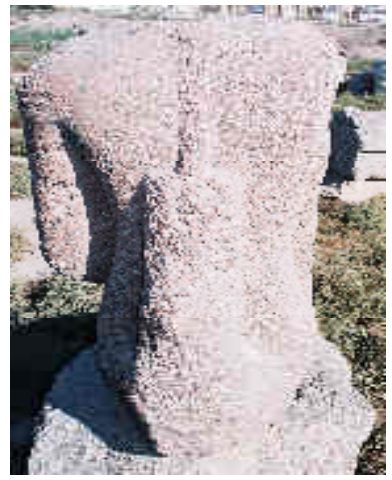

Fig. 3: The exfoliations and the granular disintegration of the granite statues.

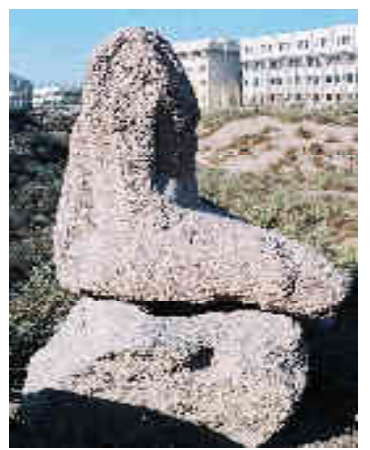

Fig. 4: The weathering and kaolinazation of granite statues.

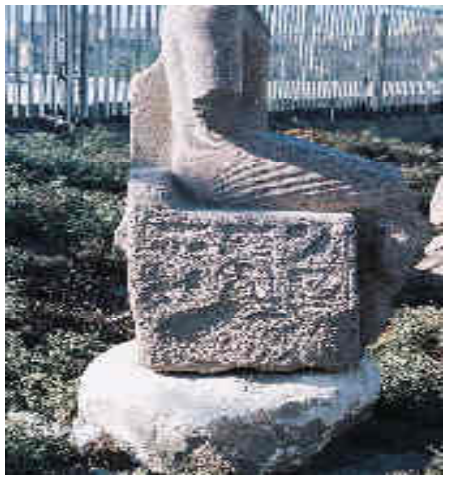

Fig. 5: Biocolonization, plant roots grow in the fractures of granite statues.

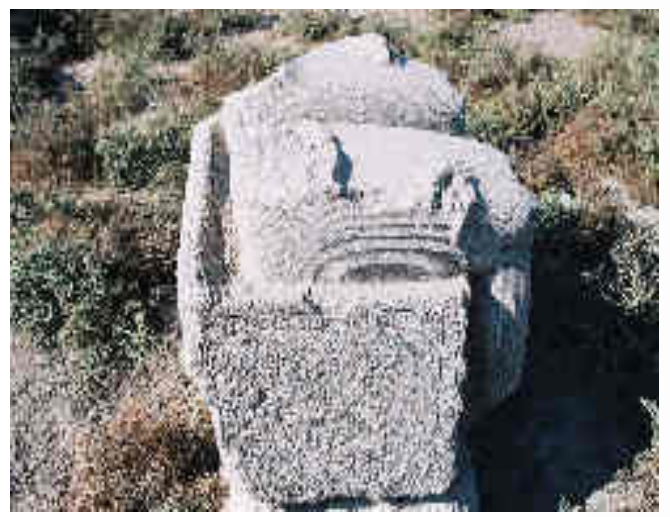

Fig. 6A: The destruction of granite statues.

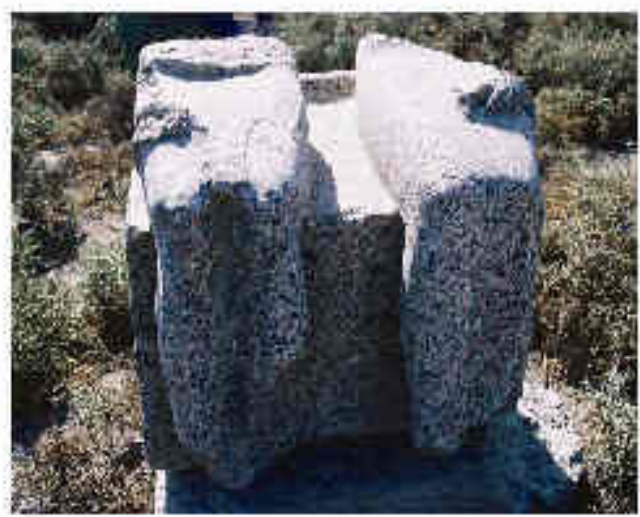

Fig. 6B: The destruction of granite statues.

Scaling of Fayoum granite statues where the sheets separate from the stone blocks parallel with the outer surface due to the disintegration of grains and separation of these grains with separation of scales of surface layer (Figs. 7, 8). Two types of 
failure might result from the temperature changes of insulation, namely exfoliation and disintegration. The granite loses cohesion because of its coarseness of grain and surface layer was cracked and flakes into falls.

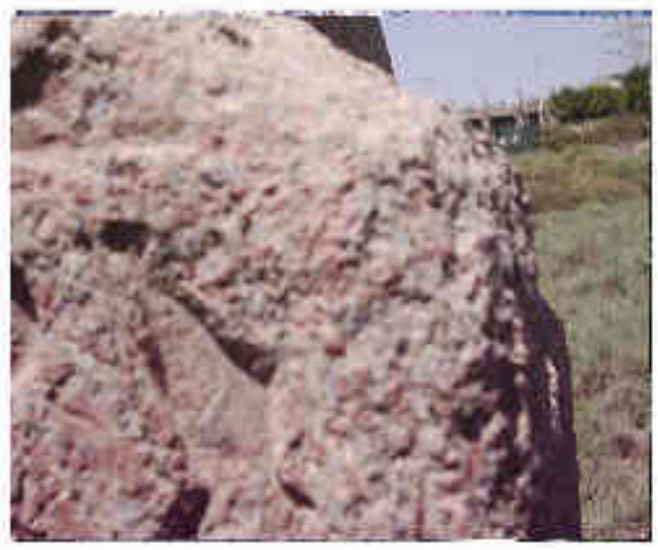

Fig. 7A: Granular disintegration is grain by grain disaggregation .

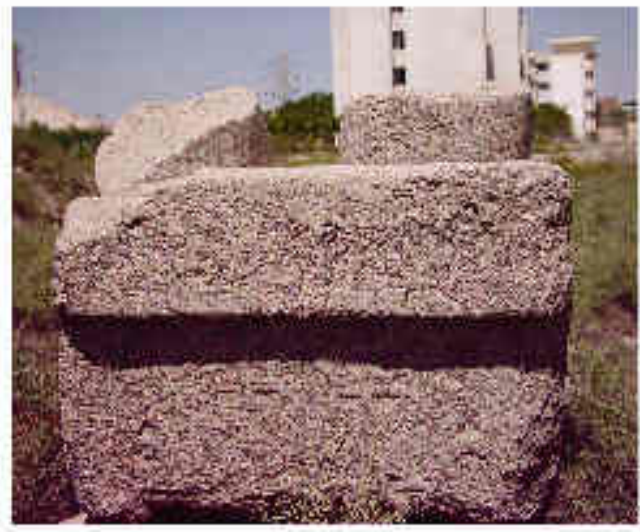

Fig. 7C: Granular disintegration is grain by grain disaggregation.

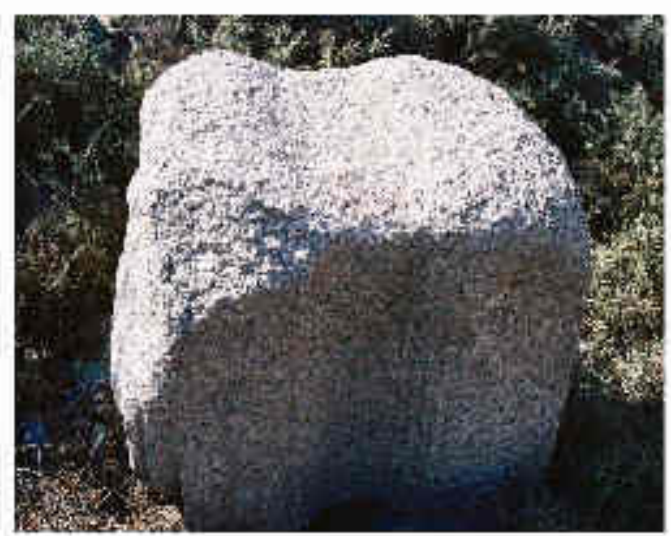

Fig. 7B: Granular disintegration is grain by grain disaggregation.

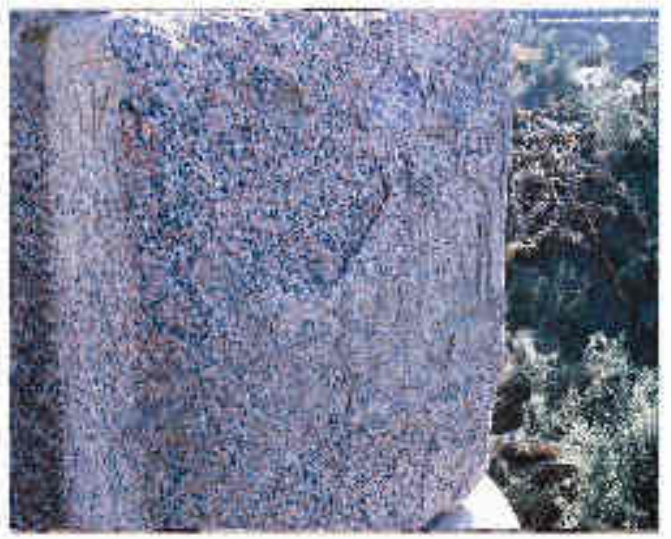

Fig. 8: Scaling is observed on granites.

The vegetation and Microbological colonization in Keman Fares plays a significant role of weathering which directly absorbing significant substantial mafic minerals ( Fig. 9) [13, 14].

Groundwater raises in this site Figs. 1,10 assists in the weathering of granite statues and the weathering of feldspars, plagioclase and biotite. 


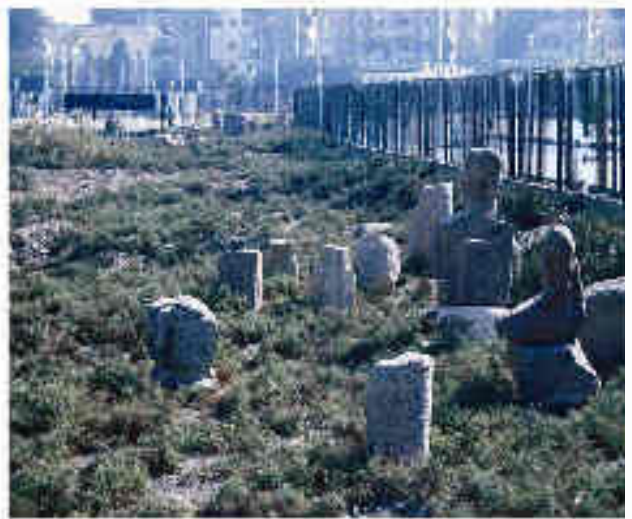

Fig. 9A: The vegetation in keman fares plays a significant role of weathering.

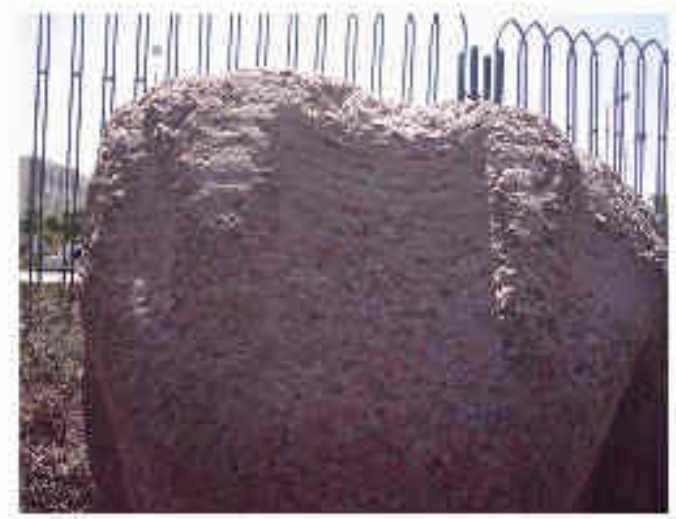

Fig. 9B: Loss of details in granite statues.

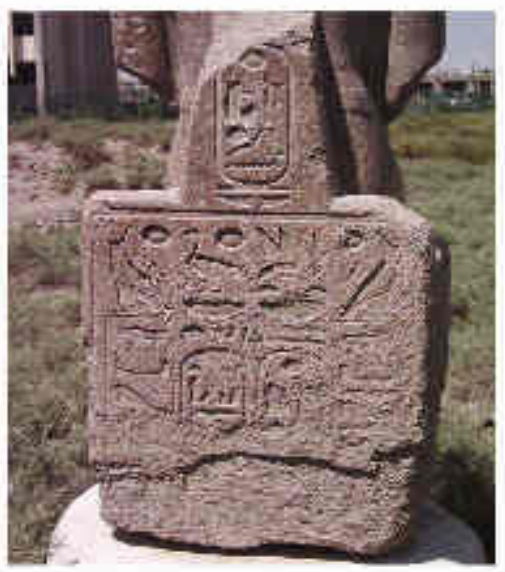

Fig. 9C: Shows scaling and exfoliation of granite statues.

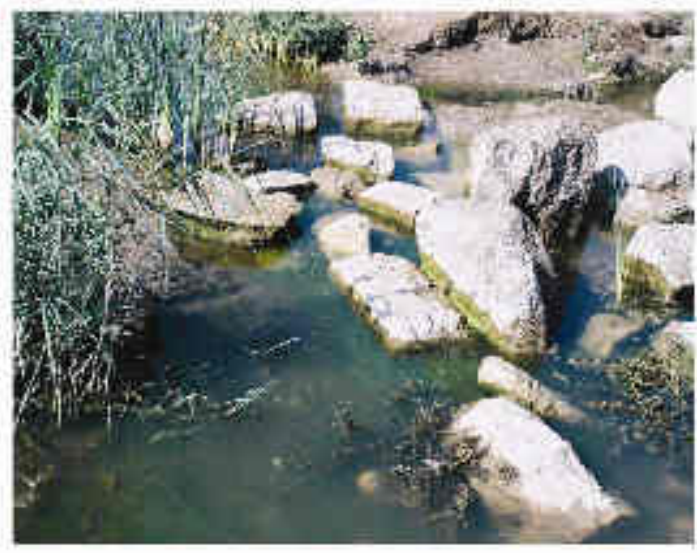

Fig. 10: The vegetation and colonization and raising of groundwater in keman faris site.

The change in relative humidity also plays a role in stone decomposition. The dark patches and the changes in the color of these statues are also detected as a result of humidity, suspended dust particles stones absorb high thermal energy of the Sun infra-red radiation which will be stored in this later due to the low thermal conduction of its minerals. This leads to change the color of the stone and disintegration of grainintergrowth forces and separation of these grains and separation of the scales of the surface layer due to the detachment and loosening of the bonds between the grains [15].

\section{MATERIAL AND METHODS}

The characterize of the deterioration of granite samples are made from observation of thin section under the polarizing microscope. The samples were 
analyses by X-ray diffraction using Philips diffractometer UK radiation in order to identify the main crystalline minerals. Scanning electron microscope (SEM) equipped with an energy dispersive X-ray microanalyses are used to study the surface features of the damaged layers.

\section{PETROGRAPHIC STUDY}

Petrographic study reveals that plagioclase and potash feldspar follow by biotite are the most susceptible primary minerals to alteration. Also potach - feldspar are highly destroyed to fine grained of silica and clay minerals to products occurs in the form of silty and clay materials and give rise to the dusty and cloudy appearance of feldspar minerals along the cleavage planes and crystal boundaries. While the alteration products of hornblend are hematite and iron oxides and a hydrous iron compound supplies the typical reddish to brown colors of granite stones.

Petrographic analysis showed that the mafic minerals hematite stained the crystals and gives highly brown pigmentation of feldspars and quartz crystals.

Orthoclase is highly divided into numerous residual dominions by a network of subparallel transverse cracks combined with some irregular longitudinal cracks (Fig. 11). Plagioclase alters and is impregnated with iron rich compounds. The internal border of the rim is highly irregular and the products of weathering irregularly penetrate the residual core along digitating and branching fissures. A transmineral fractures cut a feldspar grains by following one cleavage direction of the mineral (Fig. 12). These fractures are formed by later transition of the feldspar fragments. A long transmineral fracture cuts grains of quartz and weathered feldspars in the granite stone. The highly hydrated material has an intermediate chemical composition between that of the original feldspar and that of kaolinite. The material is slightly stained by iron oxides, a blood red to black pigmentation as a thin layer or crust (Fig. 12).

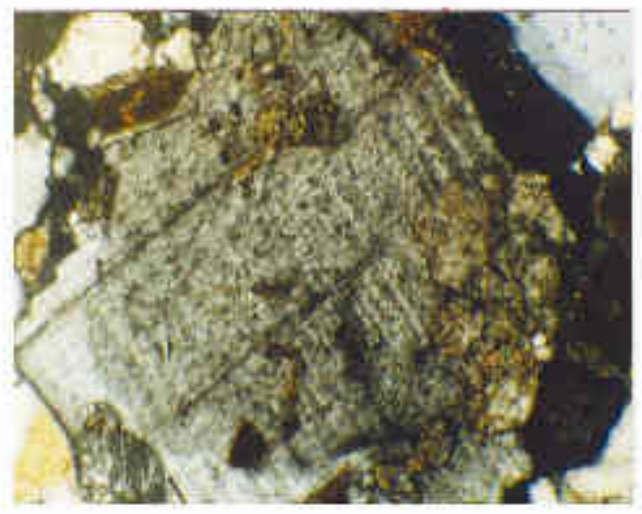

Fig. 11: Shows the alteration of plagioclase to sericite and kaolinite and gypsum. Parts of crystals are slightly altered.

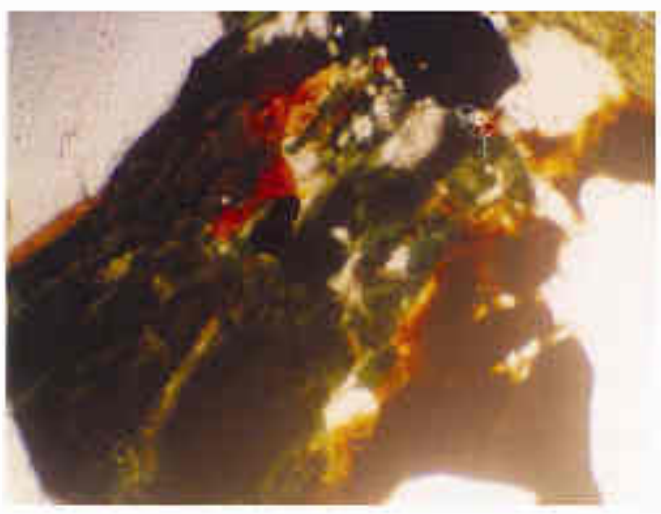

Fig. 12: Shows the alteration of biotite and plagoclase to iron oxyhydroxides (red colour) and chlorite (green colour).

Also, plagioclase is completely weathered, which is emphasized by networks of closely spaced fissures. Some open transmineral fractures are infilled by microcrystalline material as Semectite and clay minerals. Crystals of plagioclase are 
divided by a crossing network of linear fissures (Fig. 13), which follow the two intersecting cleavages of the mineral. Plagioclase is largely replaced by very fine particles of sericite appearing pale grey in (Fig. 13) The transformation of plagioclase to sericite and kaolinite is shown in (Fig. 14).

The stone contains an appreciable amount of Hornblende and biotite, both minerals exhibit good cleavage, which allow the easy development of fractures and the isolation of the less breakable components (Fig. 15).

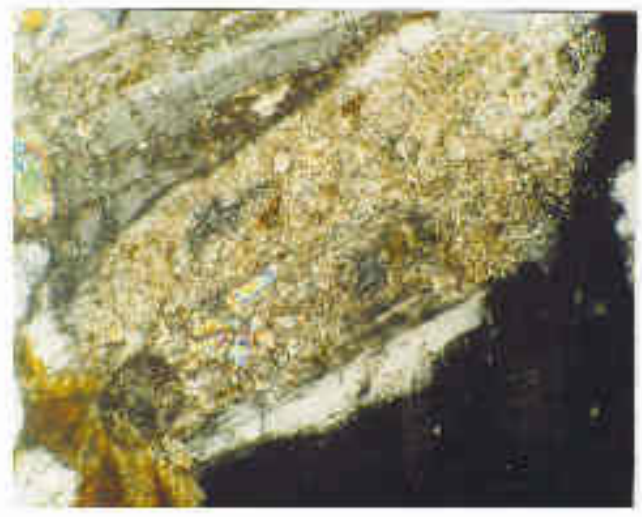

Fig. 13: Plagioclase is largely replaced by fine particles of sericite.

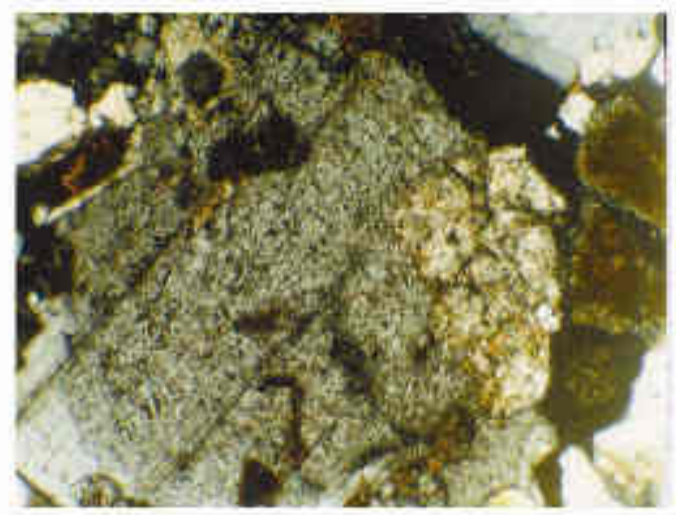

Fig. 14: Shows the alteration of feldspars to kaolinite and sericite.

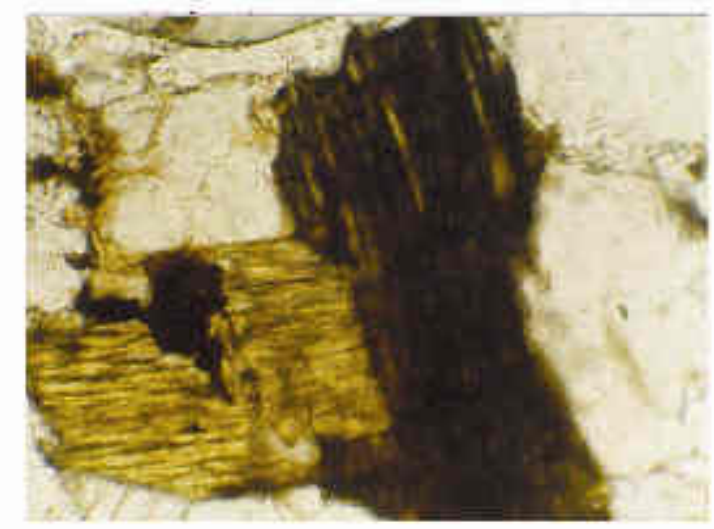

Fig. 15: The deformation of quartz and biotite. The cracks are filled by secondary material.

Biotite crystals are replaced by Kaolinite and carbonaceous manila. This replacement is accompanied by a substantial increase in volume result in the opening of many trans/and intermineral fractures (Fig. 16). This network of fractures provides the pathway for the absolute accumulation of material derived and crystallized from percolating solutions. The flakes of biotite are weathered to a smectite. The replacement generally starts along the periphery of the flakes and extends irregularly toward the center of the mineral. The weathered biotite seems to be the main source of 
the clay material of the transmineral in fillings. Also patches of gypsum as a result of alteration of are observed from deterioration (Fig. 17).

The transformation of biotite to Kaolinite and iron oxhydroxides and is the most important weathering features (Fig. 17).

The biotite has weathered to semecite. The buildup of pressure due to the swelling of the clay promoted the deformation of all the partially developed materials after biotitte into small elliptical clays. The deformation of biotite is expressed by irregular alignments of elliptical domains, which may have developed from a single crystal of biotite. The infilling material within the neighboring open fractures and pores are shown in (Fig. 18).). The red-colored layers of iron oxyhydroxides are regularly associated with lenticular or planar intramineral areas irregularly distributed around the pores and within all the extramineral pores associated with infilling of dark-brown ferruginous products (Fig. 19), and thick layers of Kaolinite are regularly distributed between more iron- rich layers; lenticular intramineral pores also present. They may be infilied by Kaolinite pigments penetrated into cracks and cleavage planes in the individual mineral grains or coating the grains as this film (Fig. 20). This pigmentation

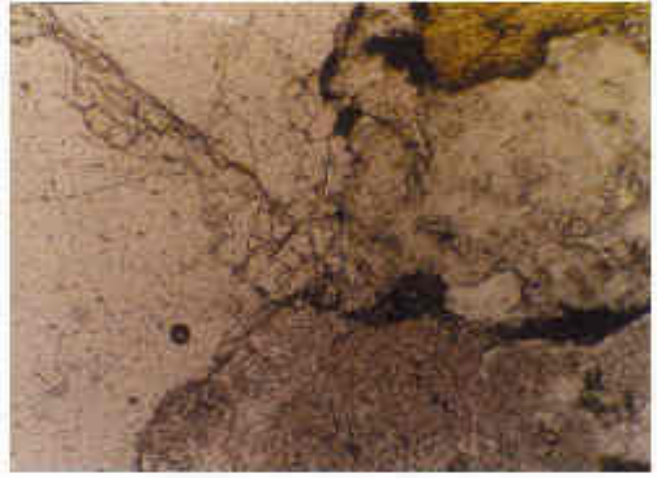

Fig. 16: Shows different cracks filled by carboneous material and the deformation of quartz .

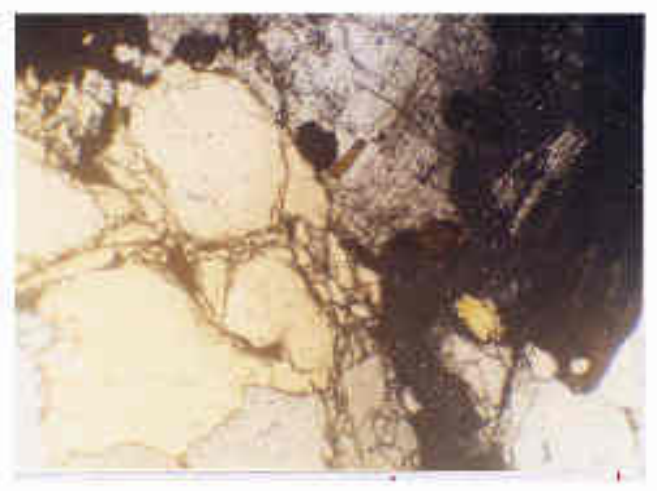

Fig. 18: Deformation of stone and the cracks are filled by carbonaceous material.

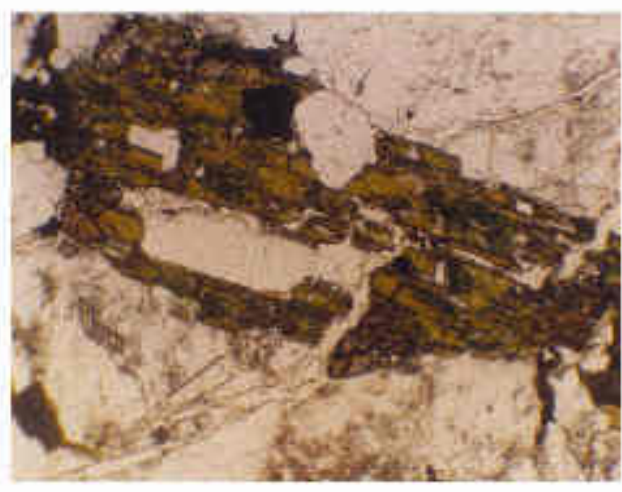

Fig. 17: The deformation and alteration of biotite to chlorite in particular through

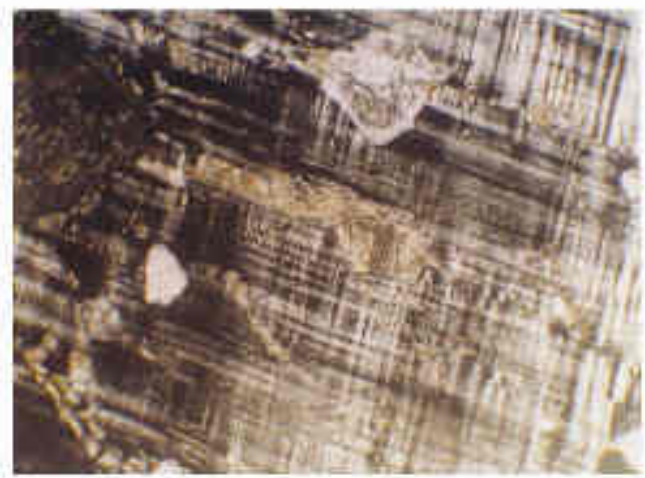

Fig. 19: The alteration of microcline to sericite and kaolinite . 
due to the degradation of the iron bearing minerals such as iron oxides (Fig. 21). All the fragments of the stone are actually separated from each other. Most of the fractures were initially accordant fractures, despite of the slow internal movements of the components. Some of these fractures are infilled by alteration products and coated by hydroxylated minerals (sericite in felspars) (Fig. 21).

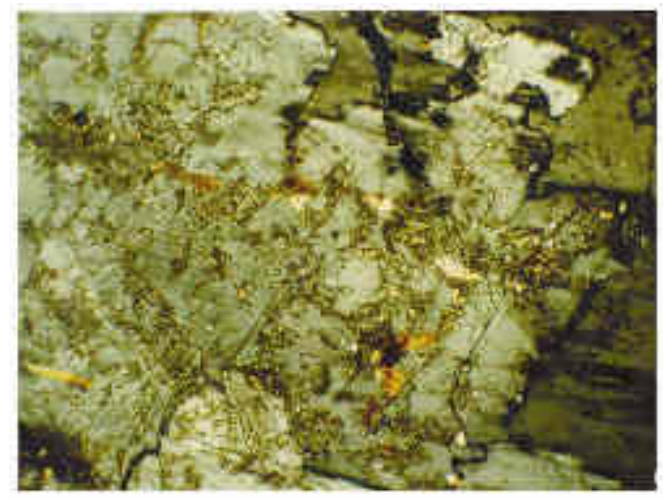

Fig. 20: The kaolinzation of orthoclase to kaolinite.

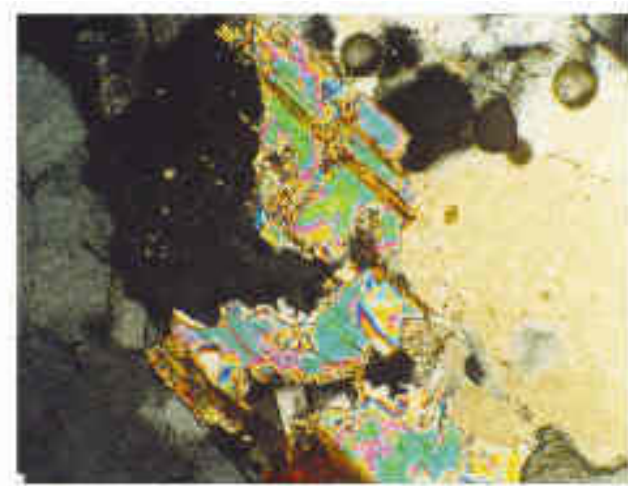

Fig. 21: The alteration of plagioclase to sericite and gypsum formation are due to air pollution .

\section{X-ray diffraction}

X-ray diffraction chart (Fig. 22) revealed the presence of plagioclase, biotite and quartz as major minerals whereas biotite, gypsum are the minor minerals X-ray diffraction (Fig. 23) shows the presence of gypsum. Gypsum is assumed to be the cause of the surface layer detachment. In the deterioration of statues, gypsum sericite, Kaolinite and chlorite are the results of weathering.

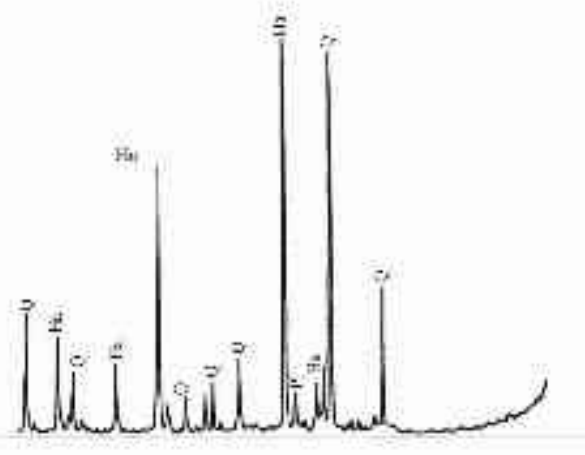

Fig. 22: X- Ray diffraction shows the presence of major and minor minerals.

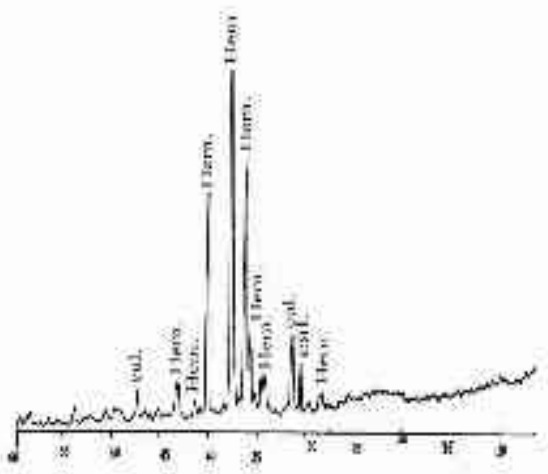

Fig. 23: X- Ray diffraction shows the presence of gypsum 


\section{Energy dispersive X-ray analysis EDX}

EDX reveals the higher concentration of iron, silicon and potassium (Figs. 24, 25) shows the increase of calcium and sulphure due to gypsum.

High iron concentration may be resulted from ferromagnetic minerals. Potassium oxide increase during alteration processes. Also potassium is most readily fixed in clay mineral with expandable lattices such as Illite, vermiculite and montmorllonite the apparent depletion in $\mathrm{Fe}_{2} \mathrm{O}_{3}$ may be attributed to removal of iron oxides attached to statues, in which transforms ferric iron to the more soluble ferrous type [10]. The reddish brown stains along fractures represent the first stage of alteration, the granite stones are intensively altered by depletion in $\mathrm{Na}_{2} \mathrm{O}$ and $\mathrm{CaO}$.

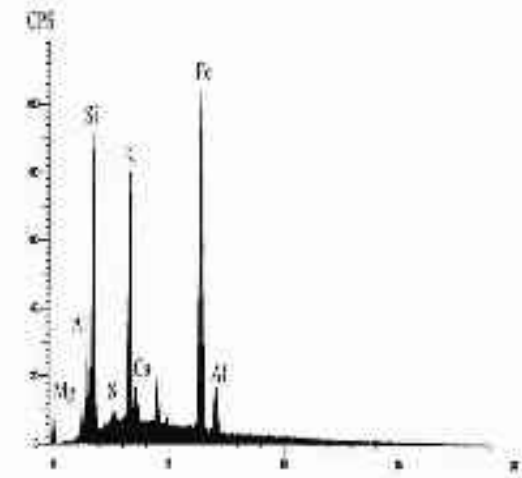

Fig. 24: EDAX shows high iron, silicon and Potassium concentration .

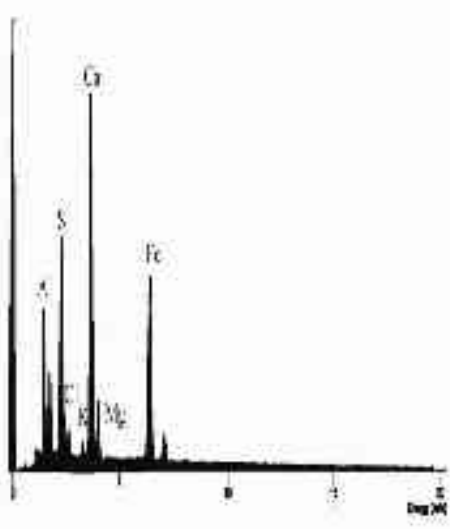

Fig. 25: EDAX Patten shows the elemental concentration of keman fares granite.

\section{X-ray Fluorescence analysis}

$\mathrm{X}$-ray fluorescence shows an apparent depletion in $\mathrm{Fe}_{2} \mathrm{O}_{3}$ due to the removal of iron oxides which transforms ferric iron to the more soluble ferrous type which responsible for the reddish brown stains along fractures. The deplation of $\mathrm{SiO} 2$ in insufficient inspit of the intensive alteration of granite stone. This is probably due to the partial reprecipitation of the $\mathrm{SiO}_{2}$ (authigenic quartz and Kaolinite) released from felsapar dissolution in $\mathrm{PH}=4$ at $25^{\circ} \mathrm{C}$ [16]. The granite stones in this site are intensively altered as manifested by depletion in $\mathrm{Na}_{2} \mathrm{O}, \mathrm{CaO}$ and high loss of ignition. Table 1 shows the analysis of weathered and unweathered granite.

\section{Scanning electron Microscope investigation SEM}

SEM shows the alveolar erosion with the increase of disaggregation in the mafic and feldspar mineral which show intensive alteration many tiny salt crystals like flowers aggregates are disseminated throughout the crystals. Microcracks are commonly extensively throughout the feldspars and mafic minerals.

In these cracks, clay minerals and calcium carbonate interspersed through the hydrolysis process. Microfractures and microcracks act as channels through which the weathering migrate and fill them with red hematite, yellow limonite and clay materials. 
Table 1: Analysis of weathered and unweathered granite.

\begin{tabular}{|c|c|c|c|c|}
\hline & \multicolumn{2}{|c|}{ Unweathered granite } & \multicolumn{2}{|c|}{ Weathered granite } \\
\hline & Sample(1) & Sample(2) & Sample(3) & Sample((4) \\
\hline Sio2 & 69.50 & 68.92 & 65.05 & 69.74 \\
\hline Tio2 & 0.47 & 0.46 & 0.45 & 0.41 \\
\hline $\mathrm{Al}_{2} \mathrm{O}_{3}$ & 13.57 & 14.03 & 16.22 & 13.48 \\
\hline $\mathrm{Fe}_{2} \mathrm{O}_{3}$ & 3.33 & 3.27 & 2.91 & 2.98 \\
\hline Mgo & 0.57 & 0.57 & 0.61 & 0.58 \\
\hline Cao & 1.96 & 1.92 & 1.57 & 1.44 \\
\hline $\mathrm{Na}_{2} \mathrm{O}$ & 3.74 & 3.98 & 2.73 & 3.55 \\
\hline $\mathrm{K}_{2} \mathrm{O}$ & 5.65 & 5.88 & 0.72 & 6.06 \\
\hline $\mathrm{P}_{2} \mathrm{Os}$ & 0.17 & 0.17 & 0.14 & 0.16 \\
\hline L.O.T & 0.87 & 0.72 & 2.44 & 1.33 \\
\hline
\end{tabular}

Numerous points of sericite and fine grained muscovite aggregates are disseminated throughout highly weathered plagioclase. Many of perthite crystals are cracked, sericitized and kaolinite. Perthite is formed of veinlets, patches and films of sodic plagioclase integrown with potash feldspar. The thermal expansion and contraction take place differential stresses causes break up the perthite along the boundaries between the two minerals which represent to weakness planes and acceleration the weathering process.

Alternating of swelling and shrinking which cause disruption of the biotite along the boundaries between biotite and alkali feldspars inclusion.

Small patches of feldspars crystals with relatively smooth surface found between the salt efflorescence representing the remains of replaced feldspar crystals. Also feldspars crystals show a highly weathered, a dusty, cloudy appearance and a completely disintegration as a result of salt action.

SEM micrographs revealed different microcracks inside the mineral constituents, Fig. 26. Microcracks show long, narrow sharp ended cracks. SEM analysis shows microfractures and microcracks inside the mineral grains with the dissolution cavities Fig. 27. Figure 28 shows the strong deformation and transformation of feldspars to clay minerals. SEM micrographs shows the presence of halite and gypsum crystals within the cavities and microfractures Fig. 29. SEM shows the pigmentation of the mineral grains and interspaces between the grain boundaries.

Pitting or alveolar weathering are present due to the activity of microorganism inside feldspars and biotite Fig. 30. SEM shows the efflorescence and the crystallization of salts in cavities and microcracks. SEM (Fig. 31) shows the transformation of feldspars into clay minerals along fissures and microfractures. Gypsum occurs as acicular crystals distributed in the cavities inside the stone. SEM reveals the high content of salts. 


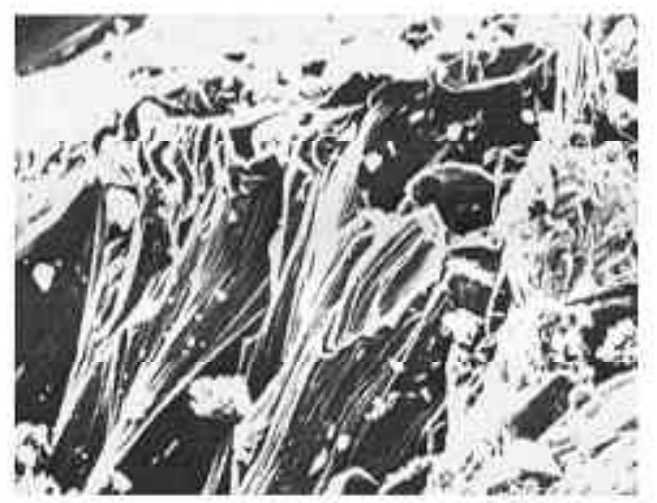

Fig. 26: SEM shows different microcracts with narrow sharp ended cracks.

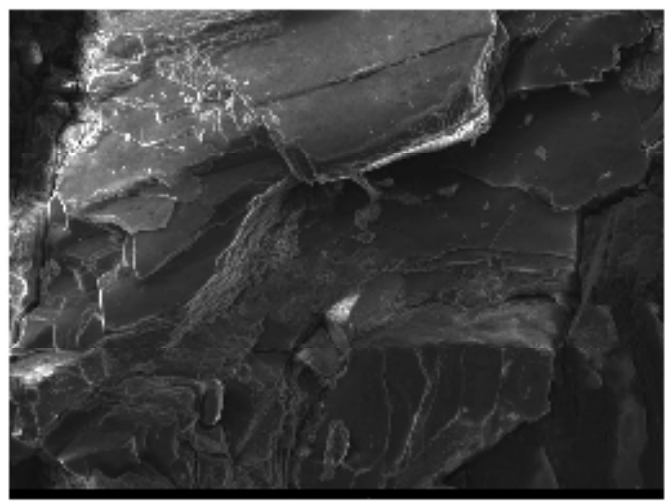

Fig. 28: The strong deformation and transformation of feldspars to clay minerals.

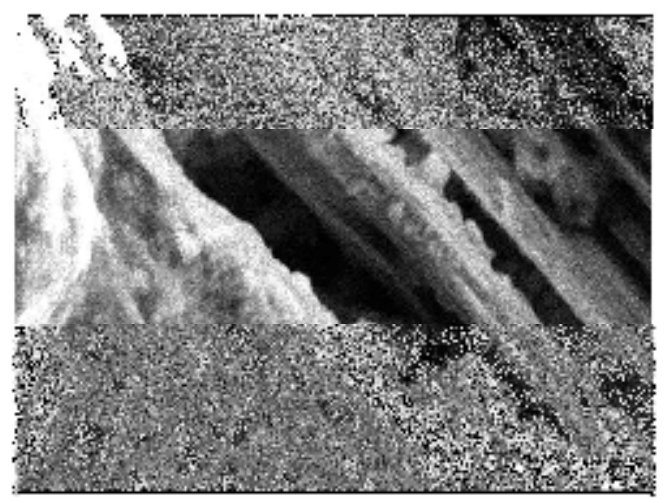

Fig. 29B: The presence of Halite and gypsum within the cavities and microfractures.

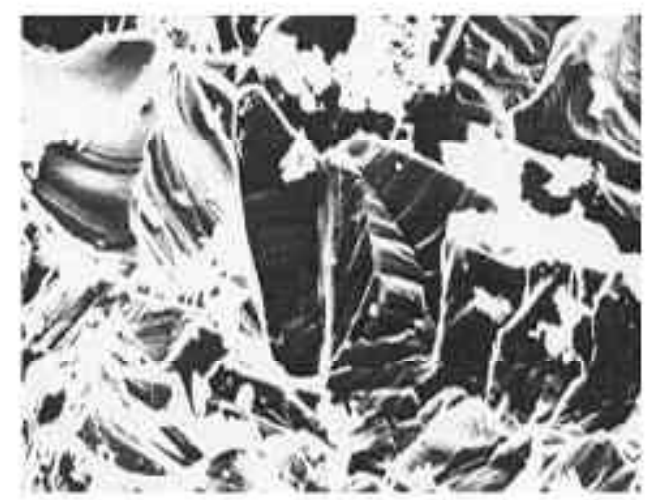

Fig. 27: SEM shows microfractures within mineral grains with dissolution cavities.

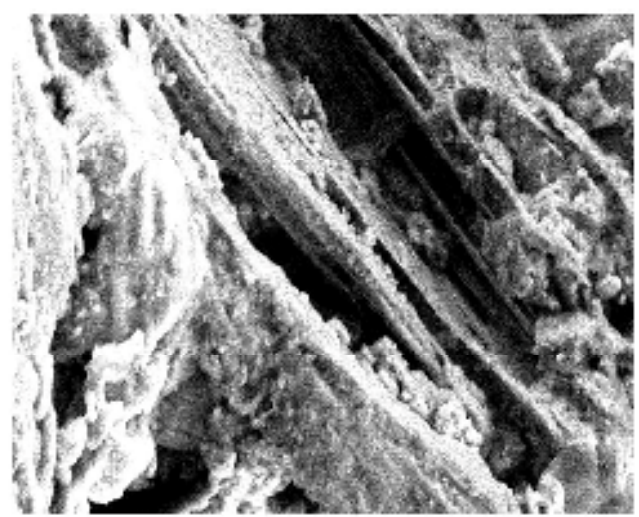

Fig. 29A: The presence of Halite and gypsum within the cavities and microfractures .

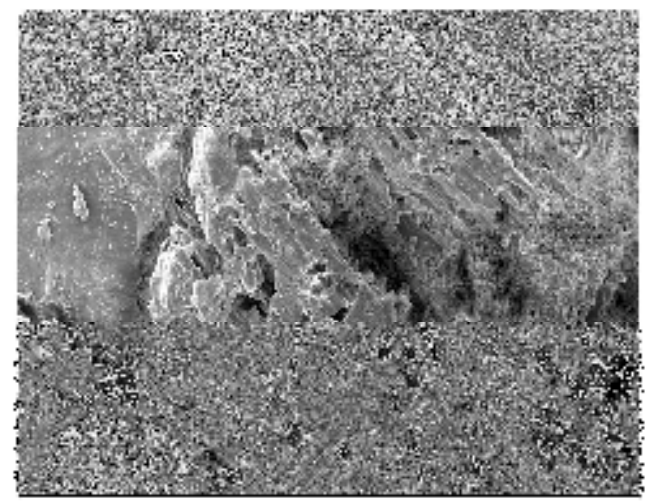

Fig. 30: The pitting and alveolar weathering due to the activity of microorganism . 


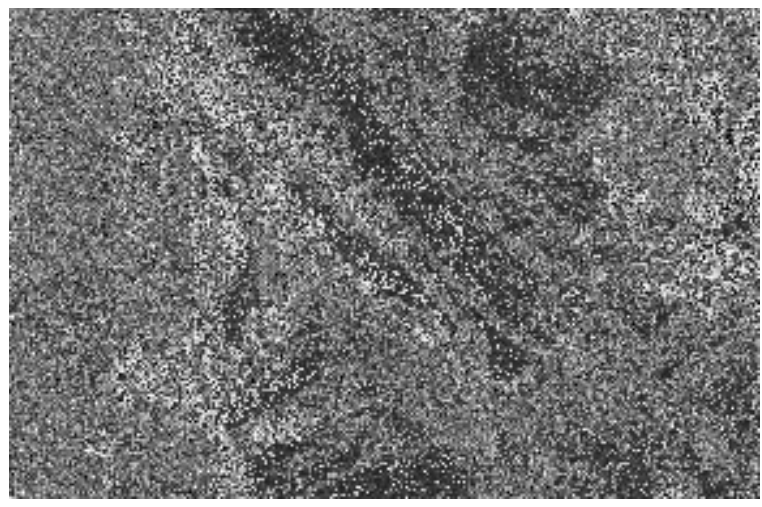

Fig. 31: The transformation of feldspars to clay minerals along fissures and microfractures .

\section{DISCUSSION}

The detailed Study of granite statues using highly advanced techniques revealed unstability of some minerals, composing granite. The minerals with cleavage are easier to be weathered and altered to more stable mineral as alteration of plagioclase with its cleavage facilitating weathering and alteration of such mineral group. The biotite composing such granite as well as muscovite it present are altered by weathering. The more stable mineral is quartz that resist most it not all weathering processes at study area.

The petrography study using thin section and scanning electron microscope are clarifying such features to an inter-pretative secondary porosity formed as net result of weathering processes that facilitate more and rapid weathering on such hard rocks.

The feldspar grains are likely to have been weathered to clay and blown, quartz grains still up, but they may soon loosened. The hydrolysis of feldspars which transformed to clay minerals, Silica in solution and carbonates. Expansion occurs when minerals are altered by water reaction with the mineral stracture by moisture, rain and groundwater. Grus is a coarse angular composed largely of quartz grains and partially decomposed feldspar crystals released upon hydration of biotite crystals. (Ritter, 1995). This due to the atoms along exposed mineral surface are not satisfied electrically and so may attract the hydrogen from the water. Hydrogen replaces the mineral cation in the internal structure of the stone and causes disintegration with aid of salt action in Kema fares when granite statues is moistened, hydrolysis occurs, producing not only a chemical alteration but expansion in volume as well. This expansion can contribute to break the granite statues and causes intensity spalling, when minerals in granite stones recat with oxygen in the air, these chemical process is called oxidation. The products of oxidation are compounds of iron and aluminum, which account for the reddish colour seen in many statues.

The rock porosity (Partically secondary porosity) is increased due to weathering of such moisture rock. The dark patches can be noticed on granite of microorganism is growing on the micro-cracks of the cleavage lattice of labile minerals composing this granite. The familiar weathering features noted on granite are due to environment condition at the study area. 


\section{REFERENCES}

[1] Dieter, A., 2003, Encyclopedia of ancient Egyptian Architecture Princeton University press.

[2] Baines J. , and Malek, J., 1989, Atlas of Ancient Egypt, les livers De france .

[3] Thompson, C, 1970, The desert Fayoum, II, P.I III CXII.

[4] Stewart Randall ; 1991, Fayoum city , The Coptic Encyclopedia, New York, vol. 4, P. 1100 .

[5] Arnold, D., 1991, Building in Egypt , pharonic stone masonry, New York and oxford, Univ. press .

[6] Rose, R. and Silv.,O., 1992, Alteration of igneous rocks by thermomechanical loads, 7th international congress on deterioration and conservation of stone, Lisbon, V.2. pp. $651-657$.

[7] Ritter, F., Craig Kochel, R. and Miller R., 1995, Process Geomorphology Wm. C. Brown Communication, Inc. Library of Congress Catalog Card Number, 9472474, Chicago.

[8] Berner, R., and Holdren, G., 1977 , Mechanism of feldspar weathering. Some observation evidence, Geology, V.5, pp. 333 - 340 .

[9] Winkler, E.M., 1973, Salt action on stone in urban building, in W. J. Joung (ED), Application of Science in Examination of works of Art, Museum of fine Arts, Boston.

[10] Carool, D., 1970, Rock weathering, New York, Plenum .

[11] Whalley , W, Bouglas, G. and Mc Greevy J., 1982, Crack propagation and associate weathering in igneous stones. Zeitschrift for Geomorphologie, N.F., 26 Pp. $33-54$.

[12] Guri,k, 1981, The deteriotation of Ancient stone structures in Egypt, imed. N. Grimal, prospection et sauvegrade des antiqutes de Egypt Cairo, Pp. 13 - 18 .

[13] Caneva, G., 1988, Tree roots and hypogeans conservation, proc. 31 int. symp. IAVS, Spontaneous vegetation and satllements.

[14] Caneva, G, and Roccard, A., 1991, Harmful flora in the conservation of Roman monuments, International congress of Biodeterioration cultural property, India, Pp. $212-218$.

[15] Helmi, E.M., 1985, Deterioration of some granite in Egypt, Vth inter. Cong. On Deterioration and Conservation of stone Lousanne. 421- 426.

[16] Tsuzuki, Y., Mizutani,s., Shimizu, H., and Hayashi, H, 1974, Kinetics of alteration of $\mathrm{k}$ - Feldspar and its application to the alteration zoning, Geochemical, J., V.8, Pp. 1-20 . 


\section{دراسة تلف التماثيل الجرانيتية بحفائر كيمان فارس بالفيوم}

\section{شحاته أحمد عبد الرحيم - مدرس بكلية الآثار - جامعة الفيوم}

يتناول البحث در اسة لتلف التماثيل الجر انيتية المكتشفة بحفائر كيمان فارس بالفيوم والتي التي التئي

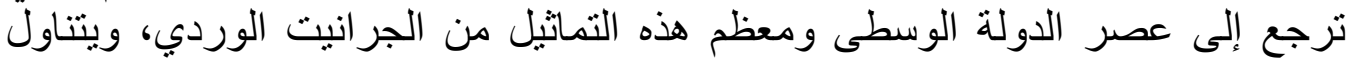

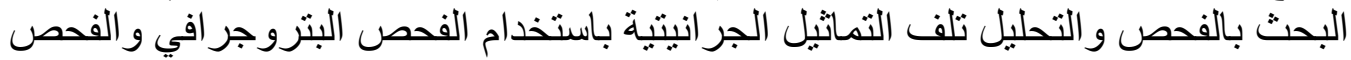

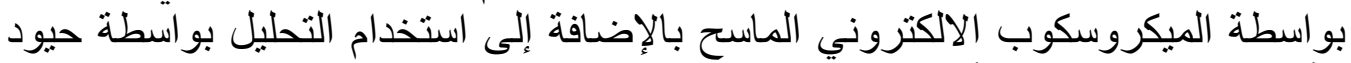

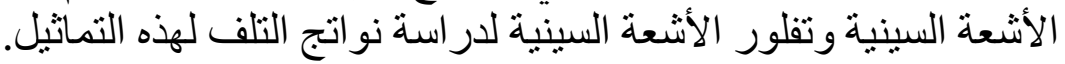

ويثتمل البحث على دراسة العو امل البيئية المؤثرة على هذه التماثيل الجر انيتيـة ومظاهر

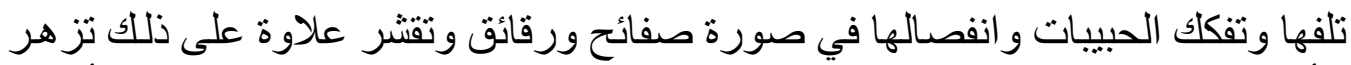

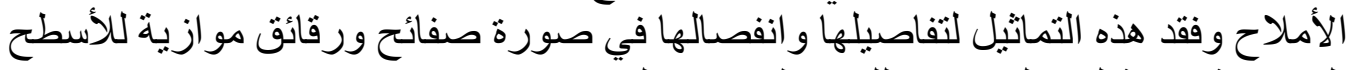
الخارجية نتيجة لفقد الجر انيت للرو ابط ما بين الحبيبات.

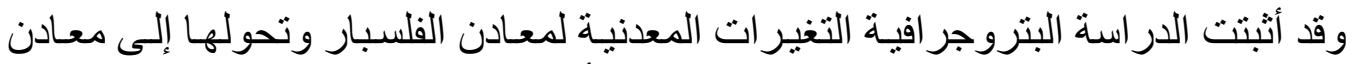

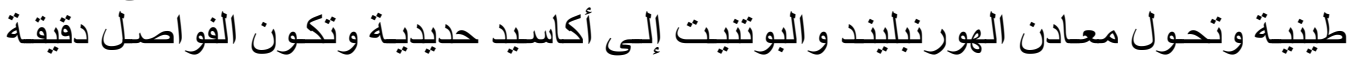

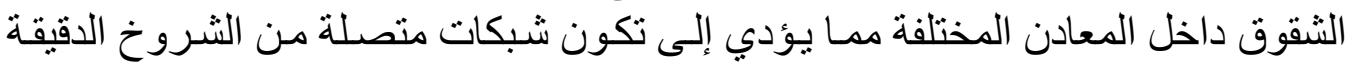
التي تزيد من تلف التماثيل الجر انيتية.

كما ثبت باستخدام حيود الأشعة السينية ظهور أمـلاح الجبس نتيجـة لعوامل التلف البيائيسة

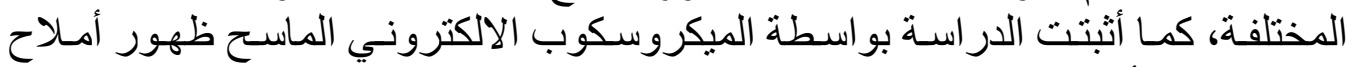

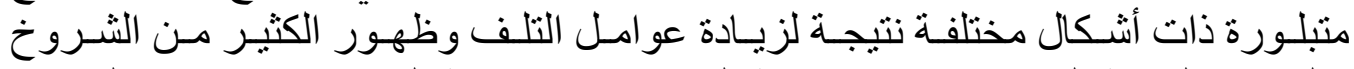

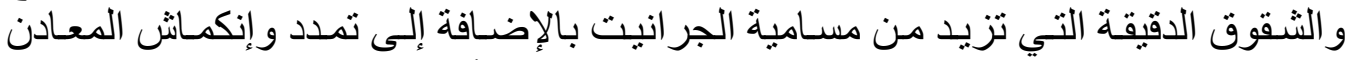

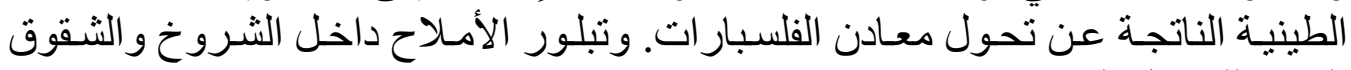
الدقيقة للتماثيل الجر انيتية.

ويقدم البحث مسببات و عو امل التلف المختلفة التي تفيد في تشـخيص و عـلاج وصيانة التماثيل الجر انيتية. 